\title{
Application of Geospatial Technology for Wetlands' Mapping and Change-Detection: A Case Study in Selected Areas of South Eastern Coast in Ampara District, Sri Lanka
}

\author{
ILM. Zahir ${ }^{1, a}$, K. Nijamir ${ }^{1, b^{*}}$ \\ ${ }^{1}$ Department of Geography, South Eastern University of Sri Lanka \\ azahirilm_gis@seu.ac.lk, ${ }^{\mathrm{b}}$ knijamir@gmail.com
}

Keywords: wetland, remote sensing, toposheet, Google Earth, new settlement

\begin{abstract}
In global context, the anthropogenic pressure increases the loss of wetland and its resources. Wetlands and estuaries are highly productive and act as critical habitats for a variety of plants, fish, shellfish, and other wildlife. The detection and evaluation of the wetland with modern technology is an important phenomenon to conserve the wetland area and its ecosystem. Remote sensing (RS) has a long history of successful applications within the field of wetland delineation, using a multitude of satellite platforms and sensors. This paper is trying to explore the object-based approach to derive the change detection of wetland of selected administrative areas of South Eastern coast in Ampara District within the period of 1991 to 2017. Further, it also explores the human activities that pressure on wetland including agricultural practices (land encroachment), new settlements, solid waste dumping, land cover changes etc. Satellite Imagery (Landsat) and topohseets were georeferenced for the overlay analysis and Ground control points with GPS also collected to secure the precision. Also, Google Earth imagery of 1991 and 2017 were collected and subjected to the GIS analysis for the conclusion. According to the results, agricultural land have increased by 9.4 per cent in 1991 and 16.4 per cent in 2017. Built-up land shows the increase of 0.1 per cent in 1991 and 2.1 per cent in 2017 and the Forest land has decreased as 80.3 per cent in 1991 and 72.2 percent in 2017.
\end{abstract}

\section{Introduction}

Wetlands has been functioning as important ecological features in any landscape. In its natural condition, wetlands supply numerous economical, and ecological benefits to local communities, including water quality protection, flood and erosion control, fish and wildlife habitat, aquatic productivity and unique opportunities for education and recreation Sri Lanka has a great variety of Wetlands, both man-made and natural. However, these Wetlands are now suffering because of inadequate management, urbanization, poverty and lack of awareness. Wetland area saturated with water for duration that is sufficient to sustain various types of hydrologic and biological activities. Wetlands are also valuable as ecosystems in their own right, providing carbon storage, biogeochemical transformations, and aquifer recharge [17].

Wetlands only cover approximately 06 percent of the surface area, it is considered an immensely important part of the global ecosystem and increasingly receiving due attention as it contributes to a healthy environment in many ways. Wetland in particular provide many critical important ecosystem services, including flood regulation, water storage, improving water quality recreation and habitat for a wide range of native and valued introduced species [1].

Wetlands are of two basic types: natural and constructed wetlands. Wetland research mainly focuses on ecological engineering and ecosystem restoration. Natural wetlands are the natural areas where water covers the soil, including swamps, marshes, fens, sloughs, and bogs. Constructed wetlands are ecosystems similar to natural wetlands, combining physical, chemical and biological processes $[12,13]$.

According to the Ramsar convention, areas of marsh, fen, peat land or water, whether natural or artificial, permanent or temporary, with water that is static or flowing, fresh, brackish or salt, including areas of marine water with the depth of which at low tide, does not exceed six meters". 
Wetlands are also areas of marsh, ponds and swamps, whether natural or artificial, permanent or temporary, with water that is static or flowing, fresh, brackish or salty, including areas of marine water, the depth of which at low tide does not exceed six meters [4].

In Sri Lanka, the total area wetlands were expected to be $0.19 \mathrm{~m}$ ha. This is for 3.0 per cent of area of the country. In Ampara District, total wetland area is approximately, 7,714 ha that is around 1.7 percent of the total area. The elimination of such wetland systems because of urbanization or other factors typically causes lake or tank water quality problems. The paddy cultivation is the major livelihood of the inhabitants of Ampara District and it has granted 20 percentages in the total rice production [14].

As the impact of climate change and land use practices in the environment have become more abundantly apparent, Remote Sensing (RS) becomes a vital tool for the assessment of the status and well-being of wetlands [4, 2]. Recent developments in Geographical Information System (GIS) and RS Technologies are providing valuable tools to assist with monitoring, inventory and management of wetlands. Many studies were undertaken regarding change detection in wetlands by using GIS/Remote sensing technologies across the world [8, 12, 19, 5, 6, 20].

In addition, wetlands are important feeding and breeding areas for wildlife. As with any natural habitat, wetlands are important in supporting species' diversity and have a complex of wetland values. Wetlands in Sri Lanka, as elsewhere are increasingly facing several anthropogenic pressures. Thus, the rapidly expanding human population, large scale changes in land use/ land cover, burgeoning development projects and improper use of watersheds have all caused a substantial decline of wetland resources of the country. Significant losses have resulted from its conversion threats from industrial, agricultural and various urban developments. These have led to hydrological perturbations, pollution and their effects. Unsustainable levels of grazing and fishing activities have also resulted in degradation of wetlands $[7,9,10,18]$

\section{Objective of the Study}

- To detect the changes, causes by anthropogenic activities on wetlands with the application of Geo-spatial technology in selected administrative areas of South Eastern Coastal areas in Ampara District from 1991 to 2017.

- To suggest remedial measures for the conservation and management of wetlands in the study area.

\section{Study Area}

In the Eastern province of Ampara District; Thirukkovil, Pottuvil and Lahugala administrative areas in which the major concern should be focused on were selected to carry out this study (see Fig. 1). This study mainly focuses on the major wetland and its associated areas including Ambalam Oya, Pannala Oya, Rufas Kulam Aru, Kangikadichi Ara, Tandiadi Ara, Saymena Ara, Karanda Oya, Heda Oya, Wila Oya, Helawa Ara, Girikula Ara, Bagura Oya, Kumbukkan Oya river basins covering about 138,222 ha. Although the basins exhibit to undulating landscape, the study area is a combination of landscape with altitudinal variation in the basins itself from flood plain areas of above basins and its rivers through old alluvium to still foot hills areas of the tertiary folds in study area. The land cover mapping using object-based image analysis which was followed by image enhancement, post-classification processing for change detection. For this, some wetlands were selected as sample. 


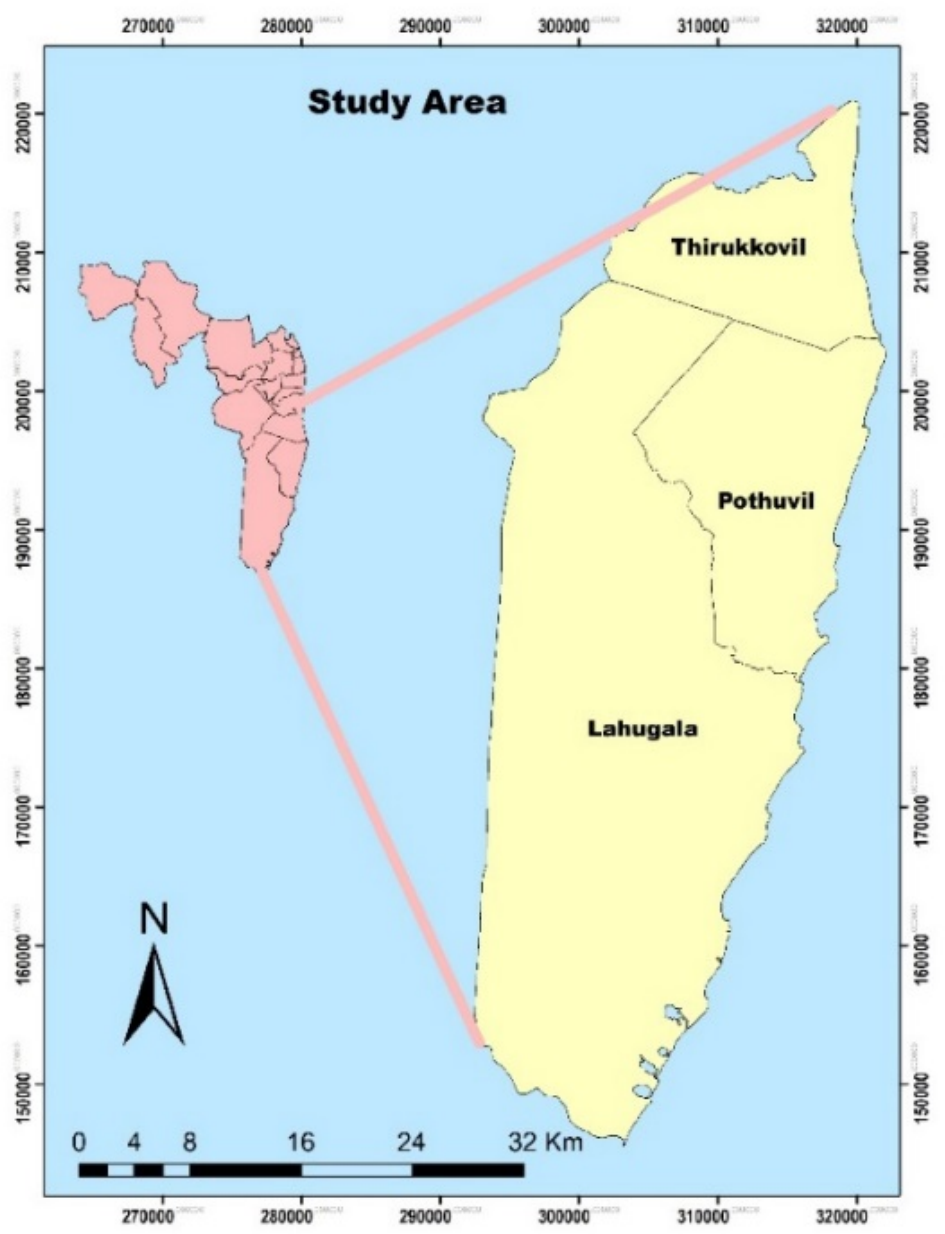

Figure 1. Study Area.

\section{Material and Methods}

Two types of data were utilized for this study namely, Toposheets and Landsat satellite image band combination 4, 3 and 2 with unsupervised classification. Google earth Image also used for further analysis. An extensive field survey was performed throughout the study area using Global Positioning System (GPS) equipment. Ground truth data was acquired for classification and accuracy assessment. RS data consist of satellite images which were under consideration with Google Earth images.

The Geo-referencing in Quantum GIS (QGIS) was also manipulated for the overlay of satellite image and Toposheet. Arc GIS 10.5 was manipulated for mapping and overlaying field data were used for object-based image analysis and accuracy assessment. Statistical data from respective agencies, published researches were used for the study.

\section{Results and Discussion}

In 1991 the wetland accounted for 4,832.5 hectare. But due to the anthropogenic pressure the amount of the wetlands have been dwindled in 2017 by 3961.2 hectares. According to the Fig. 2, tremendous declining of the wetland has been assessed. 


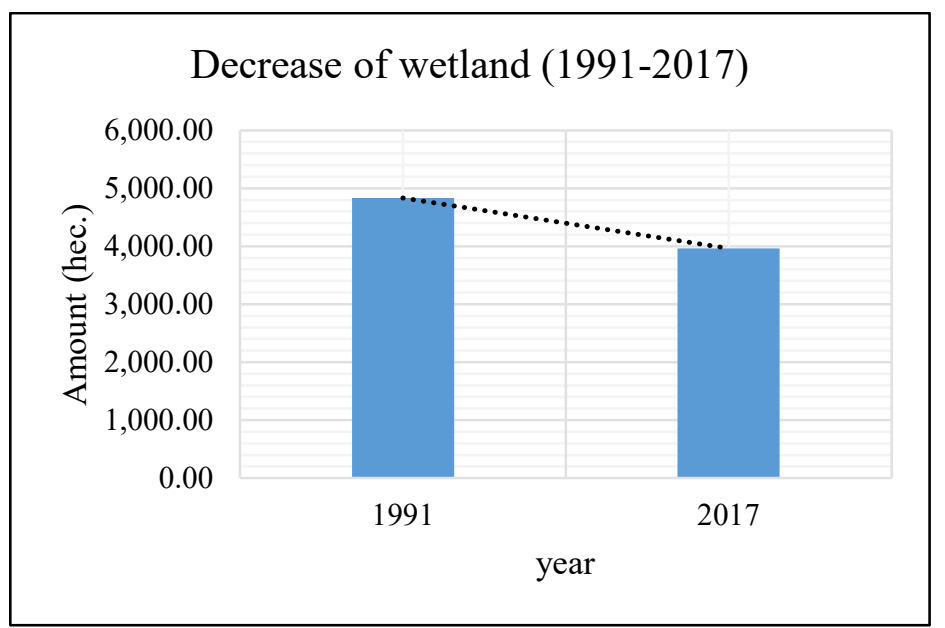

Figure 2. Change detection of wetland from 1991 to 2017.

Fig. 3 shows the changes of the wetland in the years of 1991 to 2017. Accordingly, the focused areas Thirukkovil, Pottuvil and Lahugala have lost the significant amount of the wetland due to the anthropogenic pressure.

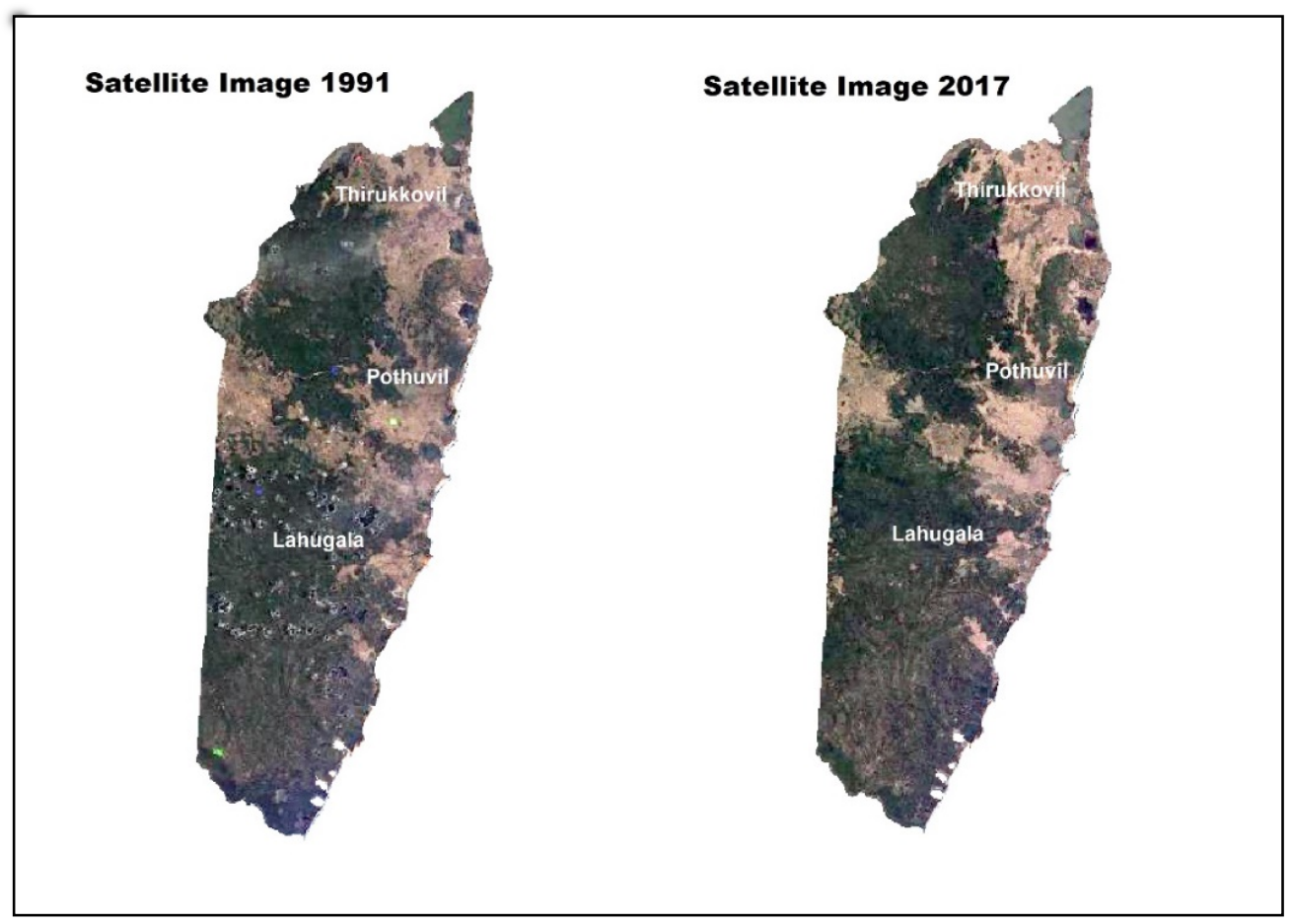

Figure 3. Satellite Images.

Fig. 4 shows the land use of the study area in 1991. Accordingly, the total area was 138,221.9 hectares of which 4,832.5 hectares accounted for wetland and it was 3.5 percent of the total land use in the study area. The abundance amount of wetland were in Thirukkovil, Pottuvil and Lahugala DS Divisions. 


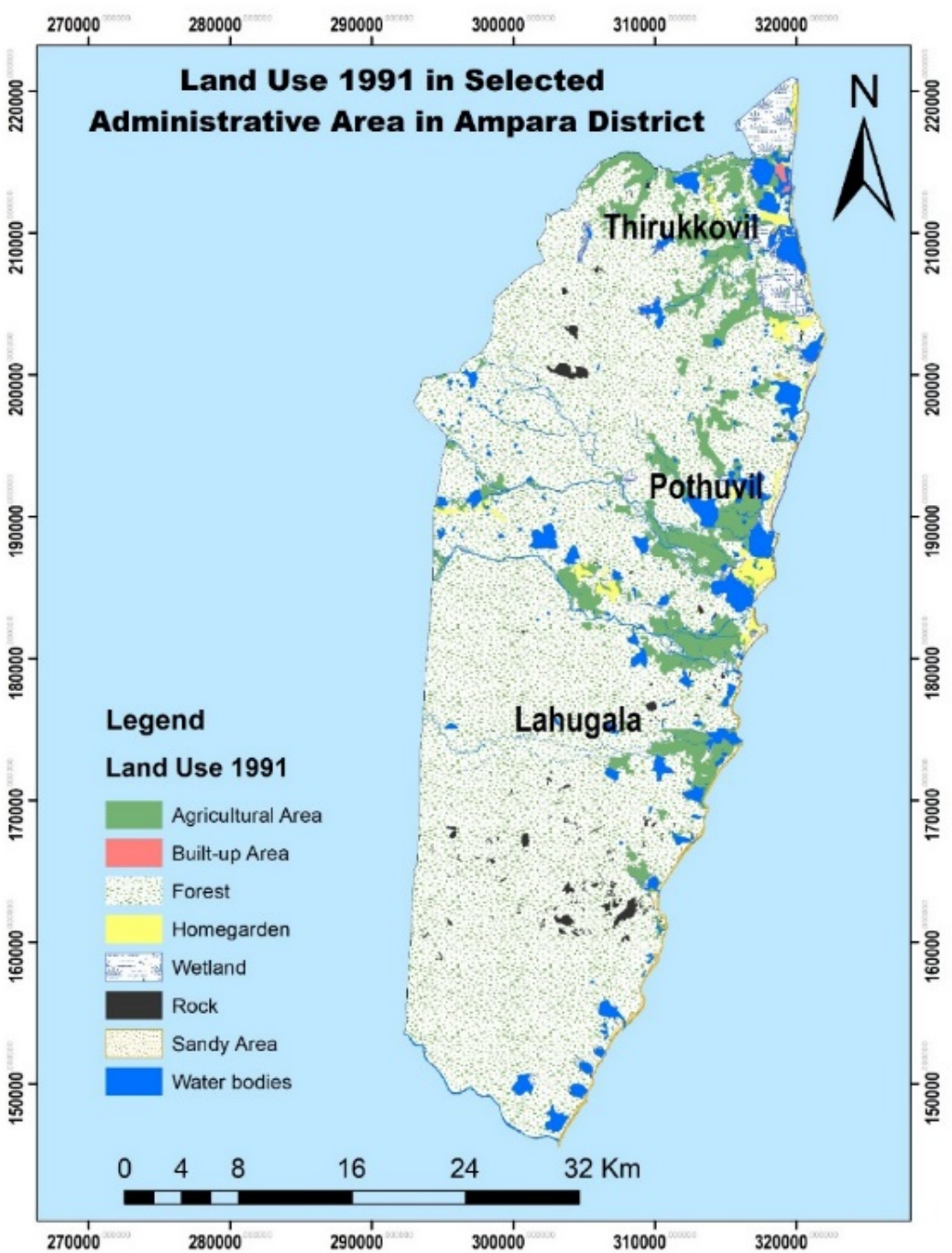

Figure 4. The land use of study area in 1991.

Fir. 5 shows the change detection of the wetland in 2017. Accordingly, the total area which was amounted in 2017 as 4,832.5 hectares have reduced as 3,961.2 hectares and assessed as 2.9 percent in total land use. Many anthropogenic activities pressured on the change of wetland accordingly. 


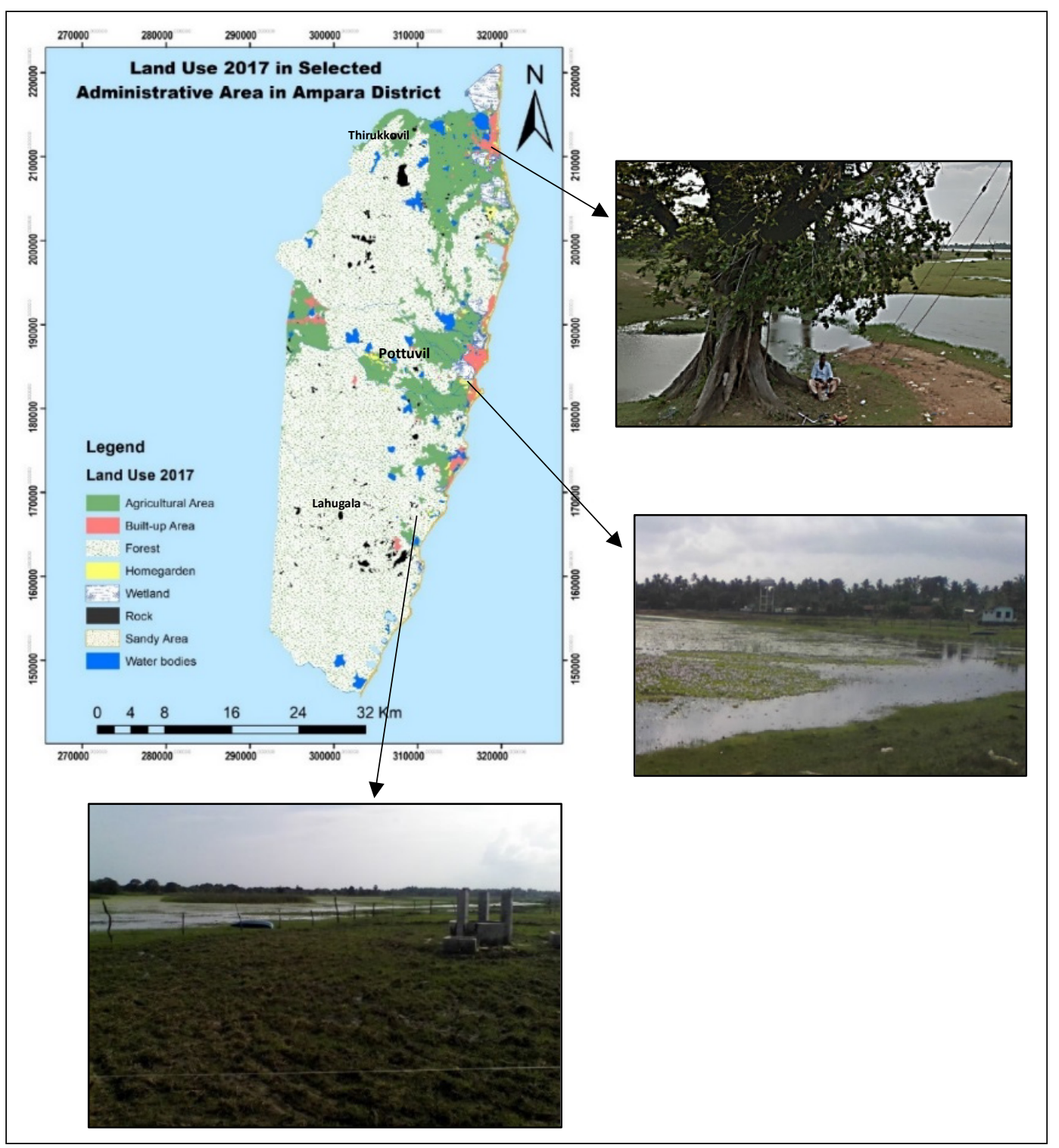

Figure 5. Change detection of wetland in 2017.

\section{Identified anthropogenic activities, pressure on the wetland}

$>$ New settlements in the study area:

New settlements in the study area have pressured on the wetland's shrinkage. Particularly, in the post-war and post-tsunami periods many people were replaced from coastal and buffer zones and they were sheltered by filling the wetlands for the makeshift houses.

$>$ Deforestation:

Erosion, biodiversity destruction and socio-economic impact triggered by the deforestation in the wetland. People from nearby places have been felling trees and hydrophytes for many purposes such as Tule mat, fire wood and fencing.

$>$ Garbage dumping:

Due to the rapid population growth in the study area, the garbage dumping also increased. This tragedy caused the environmental problems such as water and air pollution.

Land filling for play ground:

Temporary filling of the wetland for the playground caused many problems such as flooding and the damage of the green system of the wetland and its surrounding areas. 
Increased sedimentation into the wetlands due to unplanned drainage system

During the flooding, the improper drainage system causes the increased sedimentation in wetlands. Due to this process, the water storing capacity of the wetland is reduced.

$>$ Increased grassing by cattle

Cattle rearing is one of the major income sectors of the inhabitants. The people use the wetland for the cattle's grassing and the increased grassing caused the drought condition of the study.

\section{Conclusion}

Based on the application of the geospatial technology, the wetland change detection has been identified. Accordingly, the changes of the wetland caused by worse anthropogenic activities in the period of 1991 to 2017. Accordingly, the agricultural land have increased by 9.4 per cent in 1991 and 16.4 per cent in 2017. Built-up land shows the increase of 0.1 per cent in 1991 and 2.1 per cent in 2017 and the Forest land has decreased as 80.3 per cent in 1991 and 72.2 percent in 2017 . In order to minimize the pressure on the wetland: Setting up new settlement with proper land use plans; reforestation to regenerate the wetlands; proper waste management; proper drainage systems; controlling the over grassing; enact the regulation with the help of respective organizations to conserve the wetland and to provide public and stakeholder awareness are applicable measures to renew and keep the sustainability on the wetland in the study area in future.

\section{Conflict of Interest}

The authors declare that there is no conflict of interest.

\section{References}

[1] A.G. Ausseil et al., Wetland ecosystem of national importance for biodiversity: criteria, methods and candidate list of nationally important inland wetlands, Landcare Research Contract Report, 2008.

[2] A.T. Yaw, C.M. Edmund, Using remote sensing and GIS in the analysis of ecosystem decline along the river Niger Basin: the case of Mali and Niger, International Journal of Environmental Research and Public Health. 4(2) (2007) 173-184.

[3] B.I. Cook, R.L. Miller, R. Seager, Amplification of the North American "Dust Bowl" drought through human induced land degradation, Proc. Natl. Acad. Sci. 106(13) (2009) 4997-5001.

[4] B. Bezabih, T. Mosissa, Review on distribution, importance, threats and consequences of wetland degradation in Ethiopia, International Journal of Water Resources and Environmental Engineering. 9(3) (2017) 64-71.

[5] C. Marcelo, L. Cohen, J.L. Rubén, Temporal changes of mangrove vegetation boundaries in Amazônia: application of GIS and remote sensing techniques, International Journal of Remote Sensing. 11(4) (2003) 223-231.

[6] F. Hui et al., Modeling spatial-temporal change of Poyang Lake using multitemporal Landsat imagery, International Journal of Remote Sensing. 29(20) (2008) 5767-5784.

[7] F.V. Eppink, J.C.M van den Bergh, P. Rietveld, Modelling biodiversity and land use: urban growth, agriculture and nature in a wetland area, Ecological Economics. 51 (2004) 201-216.

[8] J.R. Jensen, Inland wetland change detection in the Everglades Water Conservation Area 2A using a time series of normalized remotely sensed data, Photogrammetric Engineering and Remote Sensing. 61(2) (1995) 199-209.

[9] K. Nijamir, Socio-economic impact of wetland: a study based on Navithanveli DS Division, World News of Natural Science. 14 (2017) 116-123. 
[10] L.M. Kiage et al., Recent land cover/use change associated with land degradation in the Lake Baringo catchment, Kenya, East Africa: evidence from Landsat TM and ETM+, International Journal of Remote Sensing. 28(19) (2007) 4285-4309.

[11] L. Zhanga et al., A review of published wetland research, 1991-2008: Ecological engineering and Ecosystem restoration, Ecological Engineering. 36(8) (2010) 973-980.

[12] M. Allan, Remote sensing of Waikato wetlands; a literature review, Environmental Research Institute, University of Waikato, Hamilton, 2016.

[13] M.M.X. Wang, F. Veroustraete, L. Dong, Change in area of Ebinur Lake during the19982005 period, International Journal of Remote Sensing. 28(24) (2007) 5523-5533.

[14] M.I.M. Kaleel, Challenges of population growth on agricultural land in South Eastern coastal areas of Ampara District in Sri Lanka, Sustainable Food Production. 1 (2018) 30-36.

[15] M.I.M. Kaleel, The impact on wetlands: a study based on selected areas in Ampara District of Sri Lanka, World News of Natural Sciences. 7 (2017) 2543-5426.

[16] T. Hartig et al., Tracking restoration in natural and urban field settings, Journal of Environmental Psychology. 23 (2003) 109

[17] U.S. EPA. Methods for evaluating wetland condition: study design for monitoring wetlands. Office of Water, U.S. Environmental Protection Agency, Washington, 2002.

[18] V. Klemas, Remote sensing of wetlands: case studies comparing practical techniques, Journal of Coastal Research. 27(3) (2011) 418-427.

[19] X. Yang, C.P. Lo, Using a time series of satellite imagery to detect land use and land cover changes in the Atlanta, Georgia metropolitan area, International Journal of Remote Sensing. 18 (2002) 3883-3888.

[20] Z.K. Ndirima, Mapping and monitoring wetland vegetation used by wattled cranes using remote sensing: case of Kafue flats, Zambia, MSc Thesis, International Institute for Geoinformation Science and Earth Observation, 2007. 